\title{
Still Newer Equal Protection: Impermissible Purpose Review In The 1984 Term
}

In reviewing economic or social welfare legislation under the equal protection clause, courts traditionally have applied a rationality standard: if the classification or burden imposed by the statute in question is rationally related to a legitimate governmental objective, the statute is upheld. Applying this deferential standard, courts almost always have found the requisite "rational basis."

In four cases during the 1984 term, however, the Supreme Court struck down state or municipal statutes for equal protection violations. ${ }^{1}$ The Court in each case claimed to apply the deferential rationality standard, but the opinions and holdings indicate a more searching scrutiny. The Court strengthened the rationality standard in several ways, but its willingness to examine state legislative action for impermissible purposes is the most notable change. This judicial inquiry into governmental ends involves a greater intrusion on legislative independence in economic and social welfare legislation, an intrusion that appears to have left lower courts uncertain about the substantive limits the equal protection clause now places on legislative power. ${ }^{2}$

1 City of Cleburne, Tex. v. Cleburne Living Center, 105 S. Ct. 3249 (1985); Hooper v. Bernalillo County Assessor, 105 S. Ct. 2862 (1985); Williams v. Vermont, 105 S. Ct. 2465 (1985); and Metropolitan Life Ins. Co. v. Ward, 105 S. Ct. 1676 (1985).

The Court addressed and rejected an equal protection challenge under a rationality standard in another case during the 1984 term. Northeast Bancorp, Inc. v. Board of Governors, $105 \mathrm{~S}$. Ct. 2545 (1985), discussed below in note 109. In the 1985 term, a federal statute met the rationality standard in Lyng v. Castillo, $106 \mathrm{~S}$. Ct. 2727 (1986), discussed below in note 95 and accompanying text; a Missouri statute was remanded for lower courts to apply a rationality standard, Papasan v. Allain, 106 S. Ct. 2932 (1986); and a New York statute was struck down, with the plurality applying heightened scrutiny and a concurrence relying on rationality review. Attorney General of New York v. Soto-Lopez, 106 S. Ct. 2317 (1986), discussed below in note 95 .

2 For an example of the lower courts' reaction to the new rationality standard, see Deibler v. City of Rehoboth Beach, 790 F.2d 328, 334 n.I (3d Cir. 1986) (describing the new approach as "perhaps the most sophisticated and subjective of judicial tests . . . call[ing] upon the judge's personal understanding of the needs of society") (citations omitted). In Coburn By and Through Coburn v. Agustin, 627 F. Supp. 983, 993-94 (D. Kan. 1985), the court found that heightened rational basis scrutiny was triggered by the significance of the rights at stake considered in conjunction with the sensitivity of the classifications. In turn, the court assessed the sensitivity of the classifications with reference to "traditional indicia 
This comment examines the rationality review applied in the four equal protection cases decided in the 1984 term. Part I briefly surveys the history and recent trends of equal protection analysis, emphasizing the role of rationality review. Part II analyzes the rationality standard as applied in the four cases of the 1984 term, focusing in particular on the Court's conclusions regarding impermissible purposes. Part III considers the Court's new willingness to reject certain legislative purposes as impermissible under the equal protection clause and demonstrates the legitimacy of this closer scrutiny by drawing an analogy to the paradigmatic equal protection concern-racial classifications. The analogy to race provides a preliminary understanding as to why statutory classifications that are motivated by subjective prejudice or that disadvantage the politically powerless may violate the equal protection clause even when the challenge of classification is not based on race.

\section{Rationality Review In Perspective}

\section{A. The Historical Development of Rationality Review}

Prior to the early 1960 s, the equal protection clause was of relatively little importance except in cases alleging racial discrimination; rationality review was virtually a rubber stamp of approval. ${ }^{3}$ With the Warren Court's development of a two-tiered standard of review for equal protection cases, ${ }^{4}$ however, the equal protection

of a suspect class [which] are that the class is 'saddled with such disabilities, or subjected to such a history of purposeful unequal treatment, or relegated to such a position of political powerlessness as to command extraordinary protection from the majoritarian political process.'" Id. at 994, quoting San Antonio School District v. Rodriguez, 411 U.S. 1, 28 (1973). As discussed below in notes $8 \hat{0}-103$ and accompanying text, this sensitivity to classification may be the key to understanding the Court's recent rationality cases.

${ }^{3}$ Gerald Gunther, Foreword: In Search of Evolving Doctrine on a Changing Court: A Model For A Newer Equal Protection, 86 Harv. L. Rev. 1, 8 (1972).

Chief Justice Earl Warren described the deferential nature of the traditional rational review standard as follows:

[T]he Fourteenth Amendment permits the States a wide scope of discretion in enacting laws which affect some groups of citizens differently than others. The constitutional safeguard is offended only if the classification rests on grounds wholly irrelevant to the achievement of the State's objective. State legislatures are presumed to have acted within their constitutional power despite the fact that, in practice, their laws result in some inequality.

McGowan v. Maryland, 366 U.S. 420, 425-26 (1961) (emphasis added).

The toothless nature of this standard of review is obvious when one reviews the equal protection cases from the 1930s through the 1960s: only one classification was invalidated as "wholly irrelevant" during that time. See Morey v. Doud, 354 U.S. 457, 469 (1957), overruled in New Orleans v. Dukes, 427 U.S. 297, 306 (1976).

- The two-tiered structure of equal protection analysis was foreshadowed in Chief Justice Stone's well-known footnote four in U.S. v. Carolene Products Co., 304 U.S. 144, 152 n.4 
clause developed into a powerful judicial tool restraining majoritarian rule, particularly where "discrete and insular minorities" or "fundamental rights" were involved. . Under the two-tiered standard, if the challenged classification was "suspect," such as one based on racial characteristics, or if it had a direct impact on a "fundamental right," the Court undertook "strict" scrutiny of the challenged statute; the Court sustained such classifications only if necessary to serve a compelling state interest. On the other hand, if no suspect class or fundamental right was involved, the classification was upheld if it was rationally related to valid governmental purposes; the classification merely had to have a "rational basis." In practice, the Warren Court's choice of the standard of review virtually determined the judicial outcome. "Some situations evoked the aggressive 'new' equal protection, with scrutiny that was 'strict' in theory and fatal in fact; in other contexts, the deferential 'old' equal protection reigned, with minimal scrutiny in theory and virtually none in fact."

While only racial classifications indisputably triggered strict scrutiny, ${ }^{7}$ several Warren Court decisions suggested that some other classifications deserved intensified scrutiny, including classifications based on illegitimacy ${ }^{8}$ and wealth. ${ }^{9}$ Eventually, the Burger

(1938):

There may be narrower scope for operation of the presumption of constitutionality when legislation appears on its face to be within a specific prohibition of the Constitution, such as those of the first ten amendments, which are deemed equally specific when held to be embraced within the Fourteenth.

It is unnecessary to consider now whether legislation which restricts those political processes which can ordinarily be expected to bring about repeal of undesirable legislation, is to be subjected to more exacting judicial scrutiny under the general prohibitions of the Fourteenth Amendment than are most other types of legislation. . . .

Nor need we inquire whether similar considerations enter into the review of statutes directed at particular religious, ... or national, . . or racial minorities . . . : whether prejudice against discrete and insular minorities may be a special condition, which tends seriously to curtail the operation of those political processes ordinarily to be relied upon to protect minorities, and which may call for a correspondingly more searching judicial inquiry.

Id. at 152 n.4 (citations omitted).

- Id. (suggesting higher protection for "discrete and insular minorities"); Shapiro v. Thompson, 394 U.S. 618, 634 (1969) (applying strict scrutiny to classifications burdening fundamental right to travel).

${ }^{6}$ Gunther, 86 Harv. L. Rev. at 8 (cited in note 3).

Id.

${ }^{8}$ For example, consider Levy v. Louisiana, 391 U.S. 68 (1968) and Glona v. American Guarantee Co., 391 U.S. 73 (1968), two cases in which the Court struck down wrongful death statutes that distinguished between illegitimate and legitimate children.

- In Harper v. Virginia Bd. of Elections, 383 U.S. 663, 668 (1966) (citations omitted), Justice Douglas stated: "Lines drawn on the basis of wealth or property, like those of race, 
Court developed a "newer" equal protection for quasi-suspect classifications-a "middle tier." This intermediate standard requires that classifications based on such characteristics as gender or illegitimacy "must serve important governmental objectives and must be substantially related to achievement of those objectives."10

The current three-tiered equal protection analysis is ambiguous and controversial. The middle tier, in particular, has been criticized extensively by several Justices ${ }^{11}$ as well as by commentators. ${ }^{12}$ Despite a lengthier history of application, rationality review

. . . are traditionally disfavored." The Burger Court, however, has generally refused to give heightened scrutiny to wealth-based classifications. For example, see Dandridge v. Williams, 397 U.S. 471, 483-87 (1970).

Although the Burger Court refused to extend the list of classifications requiring strict scrutiny, the standard applied in many of these equal protection decisions was a curious mixture of rationality review and strict scrutiny. See Robert W. Bennett, "Mere" Rationality in Constitutional Law: Judicial Review and Democratic Theory, 67 Cal. L. Rev. 1049, 1054-55 n.34 (1979), for an extensive summary of early Burger Court decisions that either avoided using the language of rationality review or merged it with the language of strict scrutiny. Professor Gunther has noted both the Burger Court's reluctance to expand the list of suspect classifications and the discontent of several Justices with the two-tiered system. See Gunther, 86 Harv. L. Rev. at 12-20 (cited in note 3). This discontent remained evident during the 1985 term, with Justice Marshall complaining about "the lack of vitality in this Court's recent equal protection jurisprudence," and the "Court's rigid, bipolar approach." Lyng, $106 \mathrm{~S}$. C.t. at 2732-33 (dissenting opinion) (citations omitted).

${ }^{10}$ Craig v. Boren, 429 U.S. 190, 197 (1976).

"In Craig, 429 U.S. at 221, Justice Rehnquist queried in dissent: "How is this Court to divine what objectives are important? How is it to determine whether a particular law is 'substantially' related to the achievement of such objective . . .?" Justice Powell's concurrence in the same case noted that "our decision today will be viewed by some as a 'middletier' approach. While I would not endorse that characterization and would not welcome a further subdividing of equal protection analysis, candor compels the recognition that the relatively deferential 'rational basis' standard of review normally applied takes on a sharper focus when we address a gender-based classification." Id. at 211 n.*.

While the Court has frequently affirmed that classifications in the middle tier must bear a "substantial relationship" to "important governmental interests," it has not clearly delineated the cases in which this test is applicable. One federal district court judge, referring to decisions in gender discrimination cases, noted that the Supreme Court has left lower courts with "an uncomfortable feeling, somewhat similar to a man playing a shell game who is not absolutely sure there is a pea." Vorchheimer v. School District of Philadelphia, 400 F. Supp. 326, 340-41 (E.D. Pa. 1975), rev'd, 532 F.2d 880 (3d Cir. 1976), aff'd, 430 U.S. 703 (1977).

12 See, e.g., Richard H. Seeburger, The Muddle of the Middle Tier: The Coming Crisis in Equal Protection, 48 Mo. L. Rev. 587, 615-16 (1983):

The differing positions of the various blocs suggests that an intermediate level of scrutiny as a judicial test imposes no check on policy preferences. It creates the risk of further fractionalization within the Court-with correspondingly less deliberation in judgment. Unless some manageable equal protection test is devised, it seems likely that either equal protection will have to cease being the chosen judicial tool for enforcing social justice or the Court will have to pay the price of politicization: loss of respect and institutional independence.

See also E. A. Hull, Sex Discrimination and the Equal Protection Clause: An Analysis of 
also has been subject to much criticism by commentators. ${ }^{13}$ As discussed in the next section, inconsistencies in the Court's formulation of equal protection doctrine have compounded the controversy.

\section{B. Recent Trends In Rationality Review}

In the 1970 s, the Burger Court generally applied a very deferential rationality standard when scrutinizing statutes for equal protection violations. ${ }^{14}$ In some cases, however, perhaps because

Kahn v. Shevin and Orr v. Orr, 30 Syracuse L. Rev. 639, 671 (1979) ("[T]he middle tier has no predictable application. Whether or not a given classification furthers an 'important governmental interest,' or is 'substantially related' to this interest, are subjective determinations. . . ."); Note, Refining the Methods of Middle-Tier Scrutiny: A New Proposal for Equal Protection, 61 Tex. L. Rev. 1501, 1504 (1983) ("[A]pplying intermediate scrutiny has proved difficult and has often led to confused and contradictory decisions.").

${ }^{13}$ The requirement that statutory classifications relate rationally or reasonably to a legitimate purpose creates at least two problems. First, how can the judiciary ascertain governmental purposes and judge their legitimacy? Second, what is a "rational" or "reasonable" relationship?

The first comprehensive analysis of the means-end relationship in equal protection law, Joseph Tussman and Jacobus tenBroek, The Equal Protection of the Laws, 37 Cal. L. Rev. 341 (1949), diagrammed legislative classifications in terms of over- and underinclusiveness. Despite acknowledged difficulties in ascertaining and judging legislative purposes, Tussman and tenBroek concluded that rationality requirements are both possible and necessary. Id. at $365-80$.

Not until the early 1970s did scholars question the notion of a rationality requirement. The leading articles include Michael J. Perry, Modern Equal Protection: A Conceptualization and Appraisal, 79 Colum. L. Rev. 1023, 1067-74 (1979) (arguing that the rationality requirement adds little to equal protection doctrine other than to correct "inadvertent arbitrariness"); Frank I. Michelman, Politics and Values or What's Really Wrong with Rationality Review?, 13 Creighton L. Rev. 487 (1979) (examining rationality review in terms of both economics and Rousseau's philosophy); Hans A. Linde, Due Process of Lawmaking, 55 Neb. L. Rev. 197, 201-22 (1976) (pinpointing the difficulties of using a rationality requirement in judicial review); Richard A. Posner, The DeFunis Case and the Constitutionality of Preferential Treatment of Racial Minorities, 1974 S. Ct. Rev. 1, 27-29 (describing the political process as a power struggle among interest groups, which makes a rationality requirement nonsensical); Robert Bork, Neutral Principles and Some First Amendment Problems, 47 Ind. L. J. 1 (1971) (arguing against the courts' imposition of personal values on constitutional issues); John Hart Ely, Legislative and Administrative Motivation in Constitutional Law, 79 Yale L. J. 1205 (1970) (examining the role of proof of motivation in judicial review and the rationality requirement); Note, Legislative Purpose, Rationality and Equal Protection, 82 Yale L. J. 123 (1972) (discussing the difficulty of the courts' determination as to what legislative purpose is to be used in testing classifications).

14 See Lehnhausen v. Lake Shore Auto Parts Co., 410 U.S. 356, 359 (1973) (sustaining a state constitutional amendment on taxation, noting that "the States have large leeway in making classifications and drawing lines" for taxation, and finding no "palpably arbitrary" or "invidious" motivation on the state's part); New Orleans v. Dukes, 427 U.S. 297, 303 (1976) (upholding a local economic regulation as neither invidious nor arbitrary, despite the fact that classificatory lines were drawn "with substantially less than mathematical exactitude"); Massachusetts Bd. of Retirement v. Murgia, 427 U.S. 307, 316 (1976) (declining to 
"middle-tier" equal protection scrutiny had not yet fully developed, the Court purported to apply a rationality standard when in fact it was probing the legitimacy of legislative goals and examining the significance of the interests invaded. ${ }^{15}$ As Justice Marshall noted in his dissent in Massachusetts Board of Retirement $v$. Murgia, ${ }^{16}$ the Court was particularly meticulous in scrutinizing noneconomic legislation, and its reluctance to identify what was in fact a form of heightened scrutiny confused the "true" rational relation test. ${ }^{17}$

In the early 1980 s, with the "middle tier" more firmly established in equal protection doctrine, the Court reinstated the deferential character of lower order scrutiny in the mere rationality tier. For example, in U.S. Railroad Retirement Bd. v. Fritz, ${ }^{18}$ the Court upheld a federal retirement plan despite the windfall benefits conferred on one group of retirees by a statutory classification. It affirmed the necessity of upholding legislation involving social and economic benefits, even though the laws are possibly "unwise or unartfully drawn."1s

find the elderly to be a suspect class, and upholding a statute requiring mandatory retirement for state police even though "the State perhaps has not chosen the best means to accomplish this purpose").

${ }^{15}$ See, e.g., Weinberger v. Wiesenfeld, 420 U.S. 636, 648-53 (1975) (striking down, as "archaic and overbroad," the exclusion of widowers from survivors' social security benefits); U.S. Dept. of Agriculture v. Moreno, 413 U.S. 528, 533-38 (1973) (striking down the limitation of food stamp recipients to households of related individuals as irrationally related to stated purposes of the Food Stamp Act as amended, and finding the statute's "true" purpose of preventing hippie communes to be illegitimate); Weber v. Aetna Casualty \& Surety Co., 406 U.S. 164 (1972) (striking down as irrational and loosely drawn a statute denying death benefits to the class of unacknowledged illegitimate children).

18 427 U.S. 307 (1976).

${ }^{17}$ Id. at 318-27. Justice Marshall's Murgia dissent reiterates his proposal of a "slidingscale" balancing test first suggested in his dissent in Rodriguez, 411 U.S. at 98-110. Marshall claims that his test is merely an explicit recognition of the Court's actual practice in noneconomic legislation. He contends that the Court simply balances the character of the classification and importance of the interest against the state goals. Murgia, 427 U.S. at 318. For the most recent expression of Justice Marshall's dissatisfaction with the Court's approach, see his dissent in Lyng, $106 \mathrm{~S}$. Ct. at 2732-34.

is 449 U.S. 166 (1980).

10 Id. at 175 . In that same term, writing for the Court in Minnesota v. Clover Leaf Creamery Co., 449 U.S. 456 (1981), Justice Brennan applied a highly deferential rationality standard. In reviewing the state's purposes for banning plastic milk cartons, the Court stated that "the Equal Protection Clause is satisfied by our conclusion that the Minnesota Legislature could rationally have decided" that the carton ban served its stated environmental purposes. Id. at 466 (emphasis in original). The Court said it would accept stated objectives as the actual objectives unless facts show the stated purposes were not the true ones. Id. at 463 n.7.

In other recent cases before the 1984 term the Court was deferential. In Schweiker v. Wilson, 450 U.S. 221, 237 (1981), the Court in searching for a rational relationship accepted 
Despite the deferential nature of this test, the Court employed it at least once to strike down a state statute. In Zobel v. Williams, ${ }^{20}$ Chief Justice Burger's plurality opinion concluded that Alaska's oil revenue dividend distribution plan violated the equal protection guarantee by distinguishing among Alaska residents based on years of residency. Since the statute clearly stated three purposes, the Court did not need to accept post hoc rationalizations. In scrutinizing those three purposes, the Court found no rational relationship between two of them and the classification drawn, and held the third objective impermissible. ${ }^{21}$

Several general features of rationality review before the 1984 term can be extracted from these decisions. The standard as applied did not inspire robust judicial scrutiny, apart from rare cases such as Zobel. The Court usually did not require evidence of $a c-$ tual legislative purpose; instead, post hoc rationalizations by government attorneys or second-guessing by the Court generally sufficed. In several cases the Court did not even require an actual causal relationship between legislative means and purposes; the legislature need only have rationally believed that a relationship between means and purposes existed. ${ }^{22}$ Also, the Court accepted classifications that resulted in very loose fits between means and ends. Finally, one general feature seemed to encompass the previous three. The standard of rationality was extremely low, almost to the point of being tautological: if the legislature created means to a specific end, they must perforce be rational. ${ }^{23}$

post hoc hypotheses about legislative purposes offered by the government's lawyer. In Western \& Southern Life Ins. Co. v. Bd. of Equalization, 451 U.S. 648, 672 (1981), the Court held that the legislature's rational belief in the relationship between means and ends is sufficient; no such relationship need actually exist.

${ }^{20} 457$ U.S. 55 (1982).

${ }^{21}$ Id. at 63-64. However, the statute in Zobel could not have been held unconstitutional under the equal protection clause without the recognition that it implicated the right to travel: the judgment depended on a concurrence by Justice Brennan, joined by Justices Marshall, Blackmun, and Powell, which concluded that the "threat to free interstate migration provides an independent rationale for holding that law unconstitutional." Id. at 66. Justice Burger's plurality opinion declined to address the right to travel, and instead held that attempts to distinguish between new and old residents to reward citizens for "past contributions" are not legitimate. Justice O'Connor's concurrence, id. at 72-73 nn.1-2, and Justice Rehnquist's dissent, id. at 81-83, disagreed with both the degree of scrutiny applied and the ultimate finding of irrationality. Justice O'Connor's concurrence relies not on equal protection but on the privileges and immunities clause of article IV. Id. at 71-81.

The most recent case exhibiting the Court's inability to reach a consensus in cases where equal protection concerns arguably intersect with a constitutional right to travel is Soto-Lopez, $106 \mathrm{~S}$. Ct. at 2317, discussed below in note 95 .

${ }^{22}$ See, e.g., Western \& Southern Life Ins., 451 U.S. at 672.

${ }^{23}$ See generally Note, 82 Yale L. J. at 138-39 (cited in note 13). 


\section{Rationality Review In The 1984 Term}

On four occasions in the 1984 term, the Supreme Court overturned state or municipal legislation on equal protection grounds. Each case involved economic or social welfare legislation, and in each the Court purported to apply rationality review. The most significant decision, City of Cleburne, Tex. v. Cleburne Living Center, ${ }^{24}$ reviewed a city's denial of a special use permit for a proposed group home for the mentally retarded. Metropolitan Life Insurance Co. $v$. Ward ${ }^{28}$ involved a state's distinction between treatment of resident and nonresident insurers, while Williams $v$. Vermont ${ }^{26}$ and Hooper v. Bernalillo County Assessor ${ }^{27}$ examined distributions of benefits that discriminated against newly arrived state citizens. After examining each of these decisions, this section draws the decisions together in order to assess the evolution of rationality review.

\section{A. The Cases}

1. Cleburne. The zoning ordinance challenged in Cleburne required a special use permit in residential areas only for institutions housing the mentally ill or retarded, alcohol or drug addicts, or criminals. ${ }^{28}$ Owners of the Cleburne Living Center, a proposed group home for the mentally retarded, argued that the zoning ordinance as written and applied was unconstitutional. The Court agreed.

Concluding that intermediate scrutiny was inappropriate, Justice White's opinion for the Court applied the rational basis test. The opinion reviewed the statute's purposes as given by the city council and the district court and dismissed each asserted purpose as either impermissible or as not providing a rational basis for the special use permit. The Court concluded that the first two concerns of the city council-the "negative attitudes" of nearby property owners and "fears of elderly residents of the neighborhood"-were impermissible bases for legislation. ${ }^{29}$ The Court then

24 105 S. Ct. 3249 (1985).

25105 S. Ct. 1676 (1985).

28105 S. Ct. 2465 (1985).

27105 S. Ct. 2862 (1985).

28 Cleburne, 105 S. Ct. at 3252 \& n.3.

20 Id. at 3255-59. The Court explained at length why the mentally retarded do not constitute a quasi-suspect class. Justice White's argument combined rationales based on public policy with a reluctance to increase judicial interference with state legislation by expanding the quasi-suspect category. The Court claimed that the law's treatment of the unique needs of such a diverse group is frequently "a technical matter, very much a task for legislators 
examined the lower court's and the city council's remaining justifications for the statute. These included the location of the facility across from a junior high school and on a 500-year flood plain, potential legal responsibility for the conduct of the mentally retarded, the size of the facility, the number of residents, concentration of population and congestion of the streets, fire hazards, and serenity of the neighborhood. ${ }^{30}$ While concluding that these were all legitimate considerations, the Court could not find rational justifications for treating mentally retarded individuals differently from other groups wishing to occupy the same property for different purposes. Thus, the classification was too narrowly drawn to be "rational." The Court concluded that the application of the permit requirement was motivated by an "irrational" prejudice against the mentally retarded. ${ }^{31}$

guided by qualified professionals and not by the perhaps ill-informed opinions of the judiciary." Id. at 3256 . In addition, the Court noted that governmental bodies need some flexibility to fashion remedial efforts, and that judicial scrutiny placed significant burdens on the legislature to justify its efforts. Id. at 3257 . The Court also argued that the extensive legislative response to the needs of the mentally retarded already in place belied the claim of political powerlessness. Id. Finally, the Court buttressed its conclusion with a familiar "slippery slope" argument: if the mentally retarded were considered a quasi-suspect classification, "it would be difficult to find a principled way to distinguish a variety of other groups" in similar circumstances. Id.

In disregard of this discussion, Justice Brennan in a later plurality opinion recharacterized the inquiry in Cleburne as "intensified equal protection scrutiny." Soto-Lopez, $106 \mathrm{~S}$. Ct. at 2321 .

30 Cleburne, $105 \mathrm{~S}$. Ct. at 3259. These reasons, according to the Court, "are not permissible bases for treating a home for the mentally retarded differently from apartment houses, multiple dwellings, and the like." The Court concluded that "[p]rivate biases may be outside the reach of the law, but the law cannot, directly or indirectly, give them effect." " Id., quoting Palmore v. Sidoti, 466 U.S. 429, 433 (1984).

si Cleburne, $105 \mathrm{~S}$. Ct. at 3259-60. Both concurrences in Cleburne agreed with the Court's conclusion about the ordinance's true purpose but took issue with the standard of review. Justice Stevens, joined by Chief Justice Burger, expressed discontent with "the decisional process" in equal protection cases generally. Stevens saw the cases as forming "a continuum of judgmental responses to differing classifications" rather than three distinct standards of review. Id. at 3261 \& n.4. He first articulated this approach in Craig, 429 U.S. at 212 (concurring opinion). In Cleburne, he defined "rational" as including elements of neutrality, $105 \mathrm{~S}$. Ct. at 3261-62, and posed a series of questions to guide the rational basis inquiry that make the standard quite sensitive to the specific facts of a case: "the characteristics of these groups are sometimes relevant and sometimes irrelevant to a valid public purpose, or, more specifically, to the purpose that the challenged laws purportedly intended to serve." Id. at 3262 (citation omitted). In the end, Justice Stevens found a final purported purpose of the Cleburne ordinance, to protect the mentally retarded from the "hazards" of the neighborhood, wholly unconvincing, even from the point of view of "a rational member of this disadvantaged class." Id. at 3263.

Justice Marshall, joined by Justices Brennan and Blackmun, concurred in the judgment in part and dissented in part, taking issue with the Court's holding that, since the Court found the ordinance invalid as applied, the Court need not also find it facially invalid. Id. 
2. Metropolitan Life. While in Cleburne the judgment was unanimous despite the Justices' dispute over the applicable standard of review, in Metropolitan Life Insurance Co. v. Ward ${ }^{32}$ the judgment as well as the standard of review provoked strong dissents. The Court struck down an Alabama statute that gave domestic insurers preferential tax treatment (in the form of lower gross premium tax rates) over those based out of state. Although foreign insurers could reduce their tax rates by investing in specified Alabama assets, they still could not attain the lower rate that domestic insurers enjoyed. Eschewing application of heightened scrutiny, the Court analyzed the constitutionality of the discriminatory tax according to a rationality standard. ${ }^{33}$

Since the foreign insurers had waived their right to an evidentiary hearing on whether the statute's classification bore a rational relationship to the two purposes considered by the state trial court, ${ }^{34}$ the only issue was whether those two purposes were legitimate. The two purposes were: "'(1) encouraging the formation of new insurance companies in Alabama, and (2) encouraging capital investment by foreign insurance companies in the Alabama assets and governmental securities set forth in the statute." "35

Justice Powell's majority opinion concluded that neither of these purposes was "legitimate under the Equal Protection Clause to justify the imposition of the discriminatory tax at issue." 36 The

at 3272-75. He disagreed, too, with the Court's approach: "[t] $t$ he Court holds the ordinance invalid on rational basis grounds and disclaims that anything special, in the form of heightened scrutiny, is taking place." Id. at 3263. Justice Marshall wanted the Court to use what he considered the proper label: heightened scrutiny or, in his words, "second order" rational basis review. Id. at 3264 .

32105 S. Ct. at 1676.

${ }^{33}$ In most economic legislation of this type, the statute would probably be challenged under the commerce clause. The McCarran-Ferguson Act, 15 U.S.C. $\$ \S 1011-1015$ (1982), however, exempts the insurance industry from commerce clause restrictions specifically because Congress wished to allow states to protect local insurers.

For criticism of the Court's treatment of the McCarran-Ferguson Act, see William Cohen, Federalism in Equality Clothing: A Comment on Metropolitan Life Insurance Company $v$. Ward, 38 Stan. L. Rev. 1 (1985); Spencer L. Kimball and Barbara P. Heaney, Emasculation of the McCarran-Ferguson Act: A Study in Judicial Activism, 1985 Utah L. Rev. 1.

Under the analysis considered herein, congressional action of this sort could also defuse some equal protection objections to state action, as discussed below in notes 108.09 and accompanying text. This seemed apparent in Northeast Bancorp, Inc. v. Board of Governors, $105 \mathrm{~S}$. Ct. 2545 (1985) (upholding regional discrimination of bank holding companies in the light of a federal banking statute that authorizes such action).

${ }^{34}$ The initial ruling by the trial court arose out of cross-motions for summary judgment. Thus, there was no evidentiary hearing concerning either the legitimacy of the purposes or the rational relationship. Metropolitan Life, $105 \mathrm{~S}$. Ct. at 1679.

${ }^{35}$ Id., quoting Appendix to Jurisdictional Statement 20a-21a.

so Id. at 1684 . 
Court characterized the first purpose as "purely and completely discriminatory" in its intent to promote domestic industry, "the very sort of parochial discrimination that the Equal Protection Clause was intended to prevent." ${ }^{37}$ With scant discussion, the Court dismissed the second purpose based on Justice Powell's assertion that the purpose of encouraging investment in Alabama was not legitimate when furthered "in this plainly discriminatory manner." 38

Justice O'Connor's dissent challenged both the Court's method of analysis and its conclusion, ${ }^{39}$ claiming that the majority had sidestepped the typically deferential treatment of state legislation in the economic sphere. She argued that the Court

meld[ed] the proper two-step inquiry regarding the State's purpose and the classification's relationship to that purpose into a single unarticulated judgment. This tactic enable[d] the Court to characterize State goals that have been legitimated by Congress itself as improper solely because it disagree[d] with the concededly rational means of differential taxation selected by the legislature. ${ }^{40}$

Focusing primarily on the first purpose, that of promoting local insurance companies, Justice $\mathrm{O}^{\prime} \mathrm{Connor}$ found it permissible despite its discriminatory effect for several reasons. First, she examined the "factual background" and the "collateral public benefits" of promoting local insurance companies, as set forth in the record, in the insurer's brief, ${ }^{41}$ and in the legislative history of the McCarran-Ferguson Act. ${ }^{42}$ Justice O'Connor found justification in these sources to support the constitutionality of the state goal to

${ }^{37}$ Id. at 1681-82. The Court also rejected the state's contention that equal protection analysis should not apply to taxes because it "amounts to no more than "Commerce Clause rhetoric in equal protection clothing," " id. at 1683, quoting Brief for Appellee Ward at 22. The Court maintained that the two clauses "perform different functions in the analysis of the permissible scope of a state's power. ... Equal Protection constraints are applicable even though the effect of the discrimination in this case is similar to the type of burden with which the Commerce Clause also would be concerned." Id. at 1683 (emphasis in original).

38 Id. at 1684 .

39 Justices Brennan, Marshall, and Rehnquist joined Justice O'Connor's dissent, thereby forming an unusual philosophical coalition. While Justices Brennan and Marshall more frequently vote to strike down statutes under the equal protection clause, their broad construction of the equal protection doctrine does not generally extend to cases concerning purely economic classifications. See, e.g., Cleburne, 105 S. Ct. at 3271 (Marshall, J., concurring in the judgment in part); Fritz, 449 U.S. at 193 (Brennan, J., dissenting).

to Metropolitan Life, $105 \mathrm{~S}$. Ct. at 1685.

41 Id. at 1686.

12 Id. at 1687-89. See also note 33 above. 
promote local insurance companies over foreign concerns. Second, she cited two previous Court decisions upholding discriminatory insurance taxes ${ }^{43}$ to argue that since similarly discriminatory taxation had withstood constitutional challenge, the tax in Metropolitan Life must also survive equal protection scrutiny because it did "bear a rational relationship to a legitimate state purpose." Since Alabama did not, as the majority contended, tax on the basis of residency solely to benefit local business "as an end in itself," but to serve "important ulterior goals," she argued that the statute's classification was constitutional. ${ }^{45}$

3. Williams and Hooper. Finally, two decisions, Williams $v$. Vermont ${ }^{46}$ and Hooper $v$. Bernalillo County Assessor, ${ }^{47}$ struck down legislation in which the state had granted benefits based on residency. Though the majority opinions did not explicitly recognize it, both judgments implicated the constitutional right to travel. In fact, Justice Brennan provided the critical fifth vote in concurrences that emphasized interference with that right, citing his concurrence in Zobel $v$. Williams. ${ }^{48}$

The statute challenged in Williams $v$. Vermont was a complex vehicle tax. It credited Vermont residents who purchased cars elsewhere for the amount of any sales or use tax paid to another state if that state would give a credit for taxes paid to Vermont in similar circumstances. The credit was only available, however, if the registrant was a Vermont resident at the time the initial taxes were paid. Appellants, who both purchased and registered cars outside of Vermont before becoming Vermont residents, challenged the state's failure to grant them a similar credit.

Justice White's plurality opinion found residence at the time of purchase to be a wholly arbitrary basis of classification. ${ }^{49}$ As the plurality reasoned, a state could not discriminate among taxpayers by classifying solely on the basis of residence, as Vermont had

43 See Western \& Southern Life Ins., 451 U.S. at 648; Prudential Ins. Co. v. Benjamin, 328 U.S. 408 (1946).

14 Metropolitan Life, 105 S. Ct. at 1688.

4s Id. at 1693. See id. at 1689 for O'Connor's discussion of these "important" goals, as recognized in the McCarran-Ferguson Act and in Prudential Ins. Co. In reaching this conclusion, the dissent rejected what she characterized as the majority's suggestion that a legitimate purpose could change, "chameleon-like," into an impermissible one depending on the constitutional clause invoked. Id. at 1691.

105 S. Ct. at 2465.

4105 S. Ct. at 2862.

18 Williams, 105 S. Ct at 2475 ; Hooper, 105 S. Ct. at 2869 , both citing Zobel, 457 U.S. at 65.

10105 S. Ct. at 2471-72. 
done by distinguishing between "present Vermont registrants . . . who used their cars elsewhere before coming to Vermont" and those who bought their cars in Vermont..$^{50}$

To buttress his holding that residence was an arbitrary classification, Justice White subjected the means-ends relationship to close scrutiny. A standard rationale for a use tax is that such a tax guards against lost state revenues from out-of-state automobile purchases and protects local auto dealers. The Court found this rationale inapplicable to out-of-state purchases by those who were nonresidents at the time of purchase. ${ }^{51} \mathrm{~A}$ second purpose, "Vermont's basic policy' of making those who use the highways contribute to their maintenance and improvement," tional reason" to exempt Vermont residents from the tax. ${ }^{53}$ While the exemption was rationally related to residents' out-of-state purchases, the Court maintained that offering that benefit to "old" residents while denying it to "new" ones was impermissibly arbitrary. ${ }^{54}$

so Id. at 2472 (footnote omitted) ("Having registered a car in Vermont [the two groups] are similarly situated for all relevant purposes."). After striking down the tax statute for drawing arbitrary classifications that had no rational relationship to legitimate state goals, the Court narrowed the holding considerably. It noted that the finding of irrationality precluded the need to consider arguments based on the right to travel, the privileges and immunities clause, and the commerce clause. Id. at 2474. Most significantly, the Court held the statute only facially invalid, with Justice White noting that "[i]t is conceivable that, were a full record developed, it would turn out that in practice the statute does not operate in a discriminatory fashion." Id. at 2474 (emphasis added).

s1 Id. at 2473.

${ }^{82}$ Id., quoting Leverson v. Conway, 144 Vt. 523, 532, 481 A.2d 1029, 1034 (1984), appeal dismissed for want of a substantial federal question, $105 \mathrm{~S}$. Ct. 316 (1984).

3s Williams, $105 \mathrm{~S}$. Ct. at 2473 . The Court also rejected a third purpose suggested by attorneys for the state: that the exemption was designed to enable Vermont residents to purchase cars out of state without penalty, thereby "encourag[ing] interstate commerce." Id. at 2474 .

s4 Id. at 2473-74. Justice Brennan's concurrence, which provided the necessary vote to strike down the statute, rested in addition on the ground that the tax posed an indirect threat to "federal interest in free interstate migration' . . . [and was] not 'supported by a valid state interest independent of the discrimination itself." "Id. at 2475 , quoting Zobel, 457 U.S. at 66,70 (citations omitted).

Justice Blackmun's dissent found the tax credit and exemption program rational and consistent with its stated objective of following a "user pays" principle. Thus, he argued, the statute "should easily pass the minimal scrutiny this Court routinely applies to tax statutes." Williams, $105 \mathrm{~S}$. Ct. at 2476 . He found the presumption that people generally will use a car in the state where they live to be a rational one, even if there were Vermont residents who both purchased and used a car out of state before using and registering it in Vermont. He argued that a statute does not violate "equal protection simply because it may not perfectly identify the class of people it wishes to single out. A State is not required to resort to close distinctions or to maintain a precise, scientific uniformity with reference to composition, use or value." " Id. at 2478, quoting Allied Stores of Ohio v. Bowers, 358 U.S. 522, 527 
In Hooper v. Bernalillo County Assessor, ${ }^{55}$ the Court struck down another state tax statute that favored established residents over new ones: New Mexico's lifetime property tax exemption for Vietnam veterans who established residence before May 8, 1976. ${ }^{56}$ The New Mexico Court of Appeals had relied on two statutory purposes in upholding the law: encouraging veterans to settle in the state and showing appreciation to citizens who served in the military. Since the statute specified a date of eligibility that had passed five years before the statute was enacted, the Court found it unlikely that the classification furthered the purpose of encouraging veterans to settle in New Mexico. ${ }^{57}$

The Court affirmed the legitimacy of the second purpose-compensating veterans for past service to the country-and validated classifications based on veteran status. But it held impermissible the distinction between veterans who became residents before a certain date and those who became residents later. By favoring established resident veterans, the Court argued, the New Mexico law " creates fixed, permanent distinctions . . . between . . . classes of concededly bona fide residents, based on how long they have been in the State." "\$8 Relying on the holding of Zobel, the Court found no legitimate "identifiable state purpose" in the discrimination between newcomers and established residents. ${ }^{59}$

(1959).

ss 105 S. Ct. 2862 (1985).

BE This date is one year after the last day of the Vietnam era as proclaimed by President Ford. Presidential Proclamation No. 4373, May 7, 1975, in 3A C.F.R. at 477 (1971-75 compilation).

${ }^{87}$ Hooper, 105 S. Ct. at 2867.

s8 Id. at 2869 , quoting Zobel, 457 U.S. at 59.

so Hooper, $105 \mathrm{~S}$. Ct. at 2869. As in Williams v. Vermont, the Court could not have struck down the statute in Hooper without Justice Brennan's concurring vote based on the right to travel. Id.

Justice Stevens's dissent disagreed both with the Court's reliance on Zobel and with the demand for a close fit between ends and means. He distinguished the discrimination in the Alaska dividend program in Zobel from discriminatory treatment of veterans in Hooper. 105 $\mathrm{S}$. Ct. at 2872 . In the former, those treated less favorably were a minority of newly arrived residents, and their disfavored status was permanent; in Hooper, on the other hand, "the alleged victim of the discrimination is being treated exactly like the vast majority of New Mexico's residents." Id.

More significantly, Justice Stevens found several rational reasons for the discriminatory treatment. To preserve limited resources, the state needed to restrict the size of the beneficiary class to those with a special need. Id. at 2871. Limiting eligibility to veterans who established state residency prior to May 8, 1976 would also tend to protect (if not perfectly) against "double-dippers," veterans who were already receiving assistance from other states. Id. at 2873 n.10. Stevens contended that " 'rational distinctions may be made with substantially less than mathematical exactitude." ' Id. at 2871, quoting Dukes, 427 U.S. at 303. 


\section{B. More Stringent Review: The Focus on Impermissible Purposes}

In the 1984 term, the Court was less deferential to legislative purposes and demanded more precision from states in the use of classifications to meet those ends. Although the Court remained unwilling to expand the list of classifications or interests deserving heightened scrutiny, ${ }^{60}$ the effect of the strong rationality standard created by the Court's closer scrutiny of legislative purposes and means marks a shift in doctrine that merits examination.

In addition to direct examination of legislative purposes, the Court required a "tighter fit" between the means-the challenged classification-and the asserted ends. This stricter means-ends review can be used to flush out impermissible purposes: a bad means-end fit suggests the legislature was pursuing another end. Such scrutiny is unusual in rationality review. Typically the Court has allowed that " 'rational distinctions may be made with substantially less than mathematical exactitude." "61 But in three of the four of the decisions in the 1984 term, the Court struck down statutes at least in part because the fit between the classification and the purpose was imprecise. ${ }^{62}$

60 This reluctance was most obvious in the first part of the Court's opinion in Cleburne. There, the Court articulated several concerns and problems with expanding the "list" of quasi-suspect classifications to include the mentally retarded. See note 29 above. In marked contrast, Justice Marshall's concurrence in Cleburne stressed the appropriateness of middle-tier scrutiny for classification of the mentally retarded. $105 \mathrm{~S}$. Ct. at 3270 . In addition, Justice Brennan endorsed a "fundamental right to travel" approach in his concurrences in Hooper, $105 \mathrm{~S}$. Ct. at 2869 , and Williams, $105 \mathrm{~S}$. Ct. at 2475 , and in his plurality opinion in Soto-Lopez, $106 \mathrm{~S}$. Ct. at 2323-25, discussed below in note 95.

61 Hooper, 105 S. Ct. at 2871 (Stevens, J., dissenting), quoting Dukes, 427 U.S. at 303. See also Allied Stores, 358 U.S. at 527 (a state "is not required to resort to close distinctions or to maintain a precise, scientific uniformity"); Dandridge v. Williams, 397 U.S. 471,485 (1970), quoting Lindsley v. Natural Carbonic Gas Co., 220 U.S. 61,78 (1911) ("If the classification has some 'reasonable basis,' it does not offend the Constitution simply because the classification 'is not made with mathematical nicety or because in practice it results in some inequality." ").

${ }_{62}$ For example, in striking down the vehicle tax in Williams $v$. Vermont, the Court ignored the generally valid assumption that those who reside in the state would primarily use their cars in the state, and it rejected the validity of the "user pays" rationale because it was able to find potential exceptions. $105 \mathrm{~S}$. Ct. at 2472-74. The Court also emphasized the easy availability of alternative classifications. Id. at 2472 n.8, 2473 n.9. Such searching for a less restrictive means is usually reserved for cases requiring heightened scrutiny.

In Hooper, it was easy to hypothesize a situation in which the general classification would produce an arbitrary result. The Court concluded that setting a certain date to determine eligibility for the tax exemption bore no rational relationship to the objective of encouraging veterans to settle in the state. See text accompanying notes 55-59 above. Imprecision in the means-ends fit was also a factor in Cleburne and Metropolitan Life. See text accompanying notes $28-31,32-45$ above. 
But although stricter means-end scrutiny played a role in the Court's tougher review, the hallmark of the equal protection analysis of the 1984 term was the Court's willingness to evaluate directly the legitimacy of the ends themselves, both stated and actual. In Cleburne, for example, the Court clearly stated that at least two of the stated reasons for the city council's actions, the negative attitudes of nearby property owners and the fears of elderly residents, were "mere negative attitudes" and thus "not permissible bases" for classifications. ${ }^{63}$

Judicial condemnation of stated legislative purposes is unusual enough under the rational basis test, but the Court in Cleburne went even further, looking beyond the stated rationales for what it considered to be the true motive for the statute: "the permit . . . appears to us to rest on an irrational prejudice against the mentally retarded." B4 Both Justice Stevens and Justice Marshall also investigated the legislature's actual motive or purpose. Justice Stevens's requirement of legislative neutrality or impartiality necessitated an inquiry into the motivation of lawmakers. ${ }^{65}$ According to Justice Marshall's balancing test, because society has historically discriminated against the mentally retarded, the legislation must be examined with heightened scrutiny "to assure that the hostility or thoughtlessness with which there is reason to be concerned has not carried the day."

In Metropolitan Life, too, the Court closely scrutinized the legitimacy of the stated ends. The parties' stipulation that a rational relationship existed between means and ends may partially explain the Court's emphasis on legitimacy of purposes. Rather than confine its scrutiny to the general legitimacy of the two ends that the lower court identified, however, the Court found that those ends were unacceptable when achieved by the concededly rational

(3) Id. at 3259.

st Id. at 3260 .

6s I therefore believe that we must discover a correlation between the classification and either the actual purpose of the statute or a legitimate purpose that we may reasonably presume to have motivated an impartial legislature. If the adverse impact on the disfavored class is an apparent aim of the legislature, its impartiality would be suspect. If, however, the adverse impact may reasonably be viewed as an acceptable cost of achieving a larger goal, an impartial lawmaker could rationally decide that that cost should be incurred.

Id. at 3261 n.4, quoting Fritz, 449 U.S. at 180-81 (Stevens, J., concurring in the judgment). In Cleburne, Stevens found the purpose of the permit law to be "the irrational fears of neighboring property owners." Id. at 3262 (concurring opinion).

os $105 \mathrm{~S}$. Ct. at 3268 (concurring opinion) ("the ordinance rests on impermissible assumptions or outmoded and perhaps invidious stereotypes"). 
means of classification based solely on residence. ${ }^{67}$ In this way, the Court was able to avoid condemning the legislative purpose altogether, instead focusing on the purpose as achieved by the particular classification employed. Thus, in Metropolitan Life, as the dissent argued, the majority apparently viewed any favoritism of domestic commercial entities as inherently suspect. ${ }^{68}$

Impermissible purpose review was less apparent in Hooper and Williams. In Hooper, neither of the state's asserted purposes was expressly held impermissible. Using the means-ends review to find the purposes irrationally related to the classification drawn by the statute, however, the Court flushed out what it considered to be the actual purpose- "reward[ing] only [previous residents] for their "past contributions." "6o Zobel had already held that such favoring of established residents over new residents was "not a legitimate state purpose." "7o The dissent distinguished Hooper from Zobel. "Zobel taught . . . that 'past contributions' amounting to nothing more than residence in the State does not justify discrimination;"71 in Hooper, such "past contributions" involved not merely residence but military service as well.

The Court's extremely close examination of the means-end relationship in Williams led to its holding that a state may not in any way "treat those within its borders unequally solely on the basis of their different residences or States of incorporation." a legislative classification based on residence must withstand a more exacting scrutiny. ${ }^{73}$

67 With regard to the first end, the Court stated: "under the circumstances of this case, promotion of domestic business by discriminating against nonresident competitors is not a legitimate state purpose." $105 \mathrm{~S}$. Ct. at 1684 (emphasis added). As to the second purpose, the Court held that "encouraging investment in Alabama assets and securities in this plainly discriminatory manner serves no legitimate state purpose." Id. (emphasis added).

${ }^{88}$ Id. at 1690 . The dissent further noted:

Alabama does not tax at a higher rate solely on the basis of residence; it taxes insurers, domestic as well as foreign, who do not maintain a principal place of business or substantial assets in Alabama, based on conceded distinctions in the contributions of these insurers as a class to the State's insurance objectives.

Id. at 1692 (emphasis in original).

$69105 \mathrm{~S}$. Ct. at 2869.

70 Id., quoting Zobel, 457 U.S. at 63.

7105 S. Ct. at 2872 n.6. So too in Soto-Lopez, $106 \mathrm{~S}$. Ct. at 2317 , the Court rejected a distinction based on length of residence notwithstanding the fact that the state's classification was part of a civil service preference for Vietnam veterans. The division among the justices was again apparent, with Justice Brennan writing a plurality opinion, id.; Chief Justice Burger and Justice White concurring in the judgment, id. at 2326, 2328; and Justices O'Connor, Stevens, and Rehnquist dissenting, id. at 2329.

72105 S. Ct. at 2472.

${ }^{23}$ Id. at 2472 n.8. 
The difficulty with this expansive use of impermissible purpose review lies in discerning its borders. In reviewing the relationship between means and ends, courts generally question the means (the classification itself) chosen by the legislature to implement those ends. But when a court instead examines the legitimacy of the stated or actual purpose, it may substitute its value judgment for that of the representative legislature. Judicial narrowing of legislative action that may be considered legitimate will raise serious questions regarding the courts' institutional competence and authority, especially if continued on the ad hoc basis apparently now favored by the Supreme Court. To allay these concerns, impermissible purpose review must be grounded more firmly in equal protection jurisprudence.

\section{Implications of Impermissible PuRpose Review}

\section{A. Rationality Review: A Misnomer}

Much judicial evaluation of legislation, rationality review in particular, has been attacked in recent years as overstepping the courts' institutional competence. Certainly great practical difficulties appear when courts attempt to review the legislature's choice of means and ends. While judicial evaluation of legislative purposes is an established aspect of both strict and heightened scrutiny in equal protection doctrine, ${ }^{74}$ the idea that there may be some unitary, articulated goal underlying each statutory enactment is inherently unrealistic. Even if such a purpose exists, it may not be ascertainable. ${ }^{75}$

74 See, e.g., Frontiero v. Richardson, 411 U.S. 677, 690 (1973) (government's conceded purpose of "mere administrative convenience" did not justify gender-based discrimination); Gomillion v. Lightfoot, 364 U.S. 339 (1960) (statute redefining city's boundaries was really an attempt to segregate by race and thereby deprive black citizens of the municipal vote).

${ }^{75}$ Ascertainment of purpose is the first problem, and from a practical standpoint the most difficult. A statute is the result of a group decision making process in which the majority rules. It thus makes some sense to look for the purpose motivating the majority. See John Hart Ely, Legislative and Administrative Motivation, 79 Yale L. J. at 1268 (cited in note 13). Yet, sometimes a statute may be the result of pressure from several sub-groups, each acting for different reasons, or of a minority casting the deciding votes. See Bennett, 67 Cal. L. Rev. at 1072 (cited in note 9). Bennett suggests that a "complex of purposes" may be ascertained when several groups vote for different acknowledged purposes. Another level of complexity emerges when individual legislators vote with several goals in mind, and some of those goals are unarticulated "background attitudes." Id. at 1071. See also Paul Brest, Foreword: In Defense of the Antidiscrimination Principle, 90 Harv. L. Rev. 1, 8 (1976).

Another difficulty with judicial review of purposes is that more than one purpose may actually be served by the statute. When several purposes operate, how they are scrutinized may determine the result of that scrutiny. Each stated purpose considered in isolation may not appear to be sufficiently rational to be legitimate, whereas the "mix of goals" that makes 
The Court has dealt with this practical problem in several ways. It has, on occasion, postulated conceivable purposes. ${ }^{76}$ It has also inferred the purpose from the statement of a few legislators or the words of the legislation itself. ${ }^{77}$ Generally, however, the Court will "cope with [substantial uncertainty] by doing the best [it] can with the data available." "Ts The Court has stopped short, though, of requiring legislative bodies to state clearly the purposes of statutes, recognizing its possible futility (it may result only in broad, vague, and thus virtually meaningless statements) and its potential impropriety (it may undermine the separation of powers). ${ }^{79}$

The theoretical and practical difficulties with both ascertaining and evaluating legislative purposes have led some to dispute the validity of rationality review in judicial analysis. According to some commentators, " $[t]$ he real 'justification' for most legislation is simply that it is the product of the constitutionally created political process of our society." ship between means and some vague public purpose makes little sense because "[m]any public policies are better explained as the outcome of a pure power struggle-clothed in a rhetoric of public interest that is a mere figleaf-among narrow interest or pressure groups." 81 This model of pluralist bargaining in the legislative pro-

up the full purpose may adequately support the statutory classification. See Note, 82 Yale L. J. at 135-37 (cited in note 13).

${ }^{76}$ See, e.g., Fritz, 449 U.S. at 179 (holding that where "there are plausible reasons for Congress' action, . . . [i]t is, of course, constitutionally irrelevant whether this reasoning in fact underlay the legislative decision"), quoting Flemming v. Nestor, 363 U.S. 603, 612 (1960). See also Ry. Express Agency v. New York, 336 U.S. 106, 110 (1949). Professor Bennett identifies Justice Harlan's majority opinion in Flemming as "the most forthright" articulation of the principle that the Court can hypothesize legislative purposes in undertaking rationality review. Bennett, $67 \mathrm{Cal}$. L. Rev. at 1057 (cited in note 9).

${ }^{77}$ See note 75 above and authorities cited therein for the complexities involved in identifying legislative purpose.

${ }^{78}$ Compare Bennett, $67 \mathrm{Cal}$. L. Rev. at 1073, arguing that such uncertainty is freqently handled adequately by the courts in comparable situations, with United States v. O'Brien, 391 U.S. 367, 383-84 (1968), noting the hazards of the inquiry into legislative motive.

79 But see Gunther, 86 Harv. L. Rev. at 44 (cited in note 3), arguing that the Court should require the state to articulate a purpose clearly, on the ground that this would "improve the quality of the political process [by] encouraging a fuller airing in the political arena of the grounds for legislative action."

so Posner, 1974 S. Ct. Rev. at 29 (cited in note 13).

81 Id. at 27 (cited in note 13). See also Linde, $55 \mathrm{Neb}$. L. Rev. at 197 (cited in note 13).

For other commentators, however, pluralist bargaining is not the only, or even the best, form of American democracy. Rather, they embrace a concept of deliberative democracy in which courts maintain their critical function of ensuring that certain substantive principles are not violated. See, e.g., Bruce A. Ackerman, Beyond Carolene Products, 98 Harv. L. Rev. 713 (1985); Cass R. Sunstein, Interest Groups in American Public Law, 38 Stan. L. Rev. 29 (1985); Cass R. Sunstein, Naked Preferences and the Constitution, 84 Colum. L. Rev. 1689 
cess rests on broader conceptions of the respective roles of majoritarian legislatures and countermajoritarian courts in American democracy. ${ }^{82}$

Other commentators have noted the tautological nature of rationality review:

It is always possible to define the legislative purpose of a statute in such a way that the statutory classification is rationally related to it. When a statute names a class, that class must share some common characteristic for that is the definitional attribute of a class. The nature of the burdens or benefits created by a statute and the nature of the chosen class's commonality will always suggest a statutory purpose-to so burden or benefit the common trait shared by members of the identified class. ${ }^{83}$

The Court sometimes has broken this tautology by finding certain purposes impermissible. The term "rationality review" in such instances is thus a misnomer. If a statute fails the "rationality" test, the Court is in truth finding the legislature's stated or actual purposes impermissible, imposing some positive concept of equality on the legislature. The Court usually does this indirectly by examining the legislature's choice of means and demanding a closer fit to the legislature's asserted purposes. In demanding a closer fit between means and ends, the Court "flushes out" impermissible purposes: ${ }^{84}$ if a statute's means plainly do not fit permissible ends, the Court will conclude the asserted permissible ends are a pretext for impermissible ones.

Less frequently in the past fifty years, the Court has held directly that the stated or logically inferred actual purposes of a statute were constitutionally impermissible. In the 1984 term, the Court changed this practice and directly found such an impermissible purpose in the four cases discussed above. But in doing so, it failed to define the set of impermissible purposes. Although cases in the early 1970s intimated that that legislative purposes based on

(1984).

${ }_{82}$ For general discussion of the "countermajoritarian difficulty" of judicial review, see John Hart Ely, Democracy and Distrust: A Theory of Judicial Review 4-9 (1980).

${ }^{83}$ Note, 82 Yale L. J. at 128 (cited in note 11) (footnote omitted). For an earlier description of this tautology, see Ely, 79 Yale L. J. at 1247 (cited in note 13) (" $[\mathrm{E}]$ ach choice will import its own goal, each goal will count as acceptable, and the requirement of a 'rational' choice-goal relation will be satisfied by the very making of the choice.").

B4 For example, consider Cleburne itself, where the Court examined the city's proffered purposes, found none of them served by the classification, and concluded the true motivation was simple prejudice against the handicapped. $105 \mathrm{~S}$. Ct. at 3258 . 
gender or illegitimacy were impermissible, the Court eventually created a middle level of scrutiny for these classifications rather than giving general form to the notion of "impermissible purposes." 85

The Court needs to define the set of purposes or goals that a legislature may not pursue, as well as to indicate the set of cases in which it is proper to engage in heightened scrutiny for such impermissible purposes. Only by clearly defining the actual bases of its decisions can the Court make plain its authority to exercise this particular sort of substantive review. And the need for a standard to guide lower courts (not to mention legislators) is pressing: given the Court's refusal to expand the middle tier of equal protection scrutiny even as it strengthens its lowest-order review, rationality challenges are likely to increase.

\section{B. Defining the Set of Impermissible Purposes}

Although the cases decided in the 1984 term do not purport to lay down broad guidelines, they can be made somewhat intelligible by invoking the historical goal of the equal protection clause: the elimination of state-sanctioned discrimination based on race. ${ }^{86}$ The paradigm of race has governed the Court's definition of suspect and quasi-suspect classes. ${ }^{87}$ But the potential analogies to race do not stop with these classifications: they extend to the review of purposes in the lowest tier of equal protection as well, notwithstanding the more tenuous link between means and ends that has been held permissible in rationality review. Where the analogy to race is powerful, invalidation for impermissible purposes is legitimate and consistent with equal protection doctrine.

The classifications examined in the 1984 term-the mentally retarded, nonresidents, and newly arrived residents-may not at

${ }^{85}$ For important cases in the progression, see Reed v. Reed, 404 U.S. 71, 76 (1971) (striking down gender classification that did not bear "a rational relation to a state objective"); Craig, 429 U.S. at 197 (announcing middle level scrutiny standard of substantial relation to important objective); Califano v. Goldfarb, 430 U.S. 199 (1977) (gender classifications); Trimble v. Gordon, 430 U.S. 762 (1977) (illegitimacy classifications).

${ }^{86}$ See The Slaughter-House Cases, 83 U.S. 36, 71 (1872) ("pervading purpose" of fourteenth amendment is protection of blacks). Professor Loewy has proposed that groups that are "analogous politically to a racial minority" should be able to use the equal protection clause to invalidate discrimination. Arnold H. Loewy, A Different and More Viable Theory of Equal Protection, 57 N.C. L. Rev. 1, 52 (1978). This comment proposes a similar solution, but the analysis begins not by looking for politically analogous groups, but by looking for legislative purposes that may be considered analogous to those underlying statutes premised on racial animus.

${ }^{87}$ See Loewy, 57 N.C. L. Rev. at 52 (cited in note 86). 
first glance appear to be similar to race. Yet from these cases two categories of legislation can be identified that generally are invidious in the same way that racial classifications are invidious. First, some legislative classifications are premised on nothing more than mere moral or aesthetic disapproval. Second, some classifications disadvantage groups that clearly are politically powerless. Statutes that express racial animus generally fall into one or the other category; ${ }^{88}$ both types of legislation now invite invalidation on the ground of impermissible purposes, even in the absence of decidedly racial considerations.

1. Aesthetic or moral distaste. Since the passage of the fourteenth amendment, the Court's opinions have reflected the notion that classifications based on race almost always reflect unfounded stereotypes. These stereotypes, in turn, are shaped by the prejudice, aesthetic distaste, or moral disapproval of the majority, unsupported by any objective reasoning other than a history of discriminatory attitudes and treatment. Since classifications based on gender and illegitimacy also frequently reflect such prejudice, the Court has concluded that such classifications should automatically receive heightened scrutiny as quasi-suspect classes. ${ }^{80}$ Under rationality review, however, the Court rarely has found that legislation expresses such irrational prejudice, perhaps because legislation dealing with economic matters is usually more general and thus rarely colored by systematic, entrenched negative attitudes against a certain group.

The Court's opinion in Cleburne builds on these general principles. It suggests the equal protection clause proscribes legislation based solely on subjective distaste for a particular group, even if prejudice against that group is not so entrenched and pervasive as to warrant description of that group as a suspect or quasi-suspect class. In all cases, then, the equal protection clause requires that legislative action be based on objective criteria.

The majority opinion and both concurrences in Cleburne concluded that the special use zoning ordinance was the result of "an irrational prejudice against the mentally retarded." such an irrational basis, the Court analogized the case to the para-

${ }^{88}$ One case that presents elements of both purposes in a racially motivated statute is Gomillion, 364 U.S. at 339 , where the Court held that the purpose of a statute redefining a city's boundaries was to segregate and disenfranchise blacks.

so See, e.g., as to gender classifications, Mississippi University for Women v. Hogan, 458 U.S. 718 (1982); Craig, 429 U.S. at 190; and as to illegitimacy classifications, Mills v. Habluetzel, 456 U.S. 91 (1982); Trimble, 430 U.S. at 762.

so 105 S. Ct. at 3260 . 
digm of racial discrimination. The analogy shows up in the majority's reliance on Palmore $v$. Sidoti ${ }^{91}$ a case in which the Court overturned a state child custody award to a father that was predicated on the fact that the mother (who was white) had remarried a black man. The state defended the decision as necessary to protect the child from the discrimination it might face because of the mixed marriage, but the Court replied that "[p]rivate biases may be outside the reach of the law, but the law cannot, directly or indirectly, give them effect."'92

Another previous case indicates even more strongly that the Court will deem purposes impermissible when they arise from mere distaste for or disapproval of a group. In U.S. Dept. of Agriculture v. Moreno, ${ }^{93}$ the Court struck down a federal statute that denied food stamps to households comprised of unrelated individuals. The legislative history quite clearly indicated that at least one motivating factor behind the statute was an aesthetic distaste for and attempted discouragement of the "hippie" communal lifestyle. The Court considered this distaste to be based on "a bare congressional desire to harm a politically unpopular group," and thus impermissible as a basis for legislation. ${ }^{94}$ Significantly, the Court has since upheld a similar legislative classification when it found there was no such motivation. ${ }^{.5}$

The implications of Cleburne are unclear, but they may be significant. A broad reading of the decision would be that any private preference, whether moral or merely aesthetic and whether held by a few or by a large majority, is an impermissible basis for legislation. But such a reading would be highly problematic: a great many laws, including most of the criminal code, rest largely on

91 466 U.S. 429 (1984).

82 Id. at 433.

8s 413 U.S. 528 (1973).

94 Id. at 534-35.

${ }^{85}$ In Lyng, $106 \mathrm{~S}$. Ct. at 2727, the Court upheld a recent amendment to the statutory definition of "household" in the federal food stamp program, under which parents, children, and siblings living together were treated as a single economic unit when determining food stamp eligibility and benefit levels, while no such presumption operated for other individuals living together. The Court found that close relatives as a class were not subject to vindictive prejudice, as in Moreno.

However, another equal protection decision of the 1985 term seemed to continue the course of the 1984 term. In Soto-Lopez, $106 \mathrm{~S}$. Ct. at 2317, a divided Court struck down a New York statute granting a civil service hiring preference to war veterans who were state residents at the time of entry to the military. Justice Brennan's plurality opinion applied "intensified scrutiny" because the statute violated the right of free interstate migration, id. at 2321-22, while Chief Justice Burger wrote that the statute failed the rationality test without resort to heightened scrutiny, id. at 2326. 
consensus that certain behavior is morally distasteful. Indeed, in the 1985 term the Court dramatically reaffirmed in Bouers $v$. Hardwick that laws may be predicated entirely on a community's moral or aesthetic values..$^{98}$

Such prohibitions may be acceptable when they command a broad societal consensus or when they clearly prevent harm to others. ${ }^{97}$ But they become more controversial when they prohibit private behavior or when the moral beliefs on which they rest are not universally shared: “One person's 'prejudice' is, notoriously, another's 'principle.' "98 The difficult question for equal protection jurisprudence is: when does the concept of equality prohibit a statutory classification that may be based on community values, be they "prejudice" or "principle"?

On the other hand, a narrower reading of Cleburne is possible, one that avoids suggesting the limitless principle that enforcing community values is always an impermissible purpose. The Court may have discovered some underlying factors about the nature of the community's attitudes toward the mentally retarded in Cleburne, Texas, that made them impermissible. ${ }^{100}$ This would make Cleburne a narrow ruling, one that would not imply that any classification disadvantaging the mentally retarded in any city would be invalidated. The Court would look to the facts of each particular situation to determine the extent of community prejudice. Obviously, such an inquiry would be complex and unruly. It also would be a departure from the Court's past practice of applying heightened scrutiny per se whenever it determines a

96 106 S. Ct. 2841, 2846 (1986) ("[I]f all laws representing essentially moral choices are to be invalidated . . . the courts will be very busy indeed."). (1961).

${ }^{97}$ See generally John Stuart Mill, On Liberty, in The Philosophy of John Stuart Mill

98 Ackerman, 98 Harv. L. Rev. at 737 (cited in note 81). Examples include Prohibition, Sunday blue laws, and statutes prohibiting private conduct such as homosexual activity or bigamy. For tentative suggestions that the legal system may intervene to overturn even purely private preferences, see generally, in this issue, Cass R. Sunstein, Legal Interference with Private Preferences, 53 U. Chi. L. Rev. 1129 (1986).

92 For a sampling of the extensive academic discussion of this dilemma, see Ely, Democracy and Distrust at 135-79 (cited in note 82) and, in response, Paul Brest, The Substance of Process, 42 Ohio St. L. J. 131 (1981) and Ackerman, 98 Harv. L. Rev. at 731-40 (cited in note 81).

100 "The short of it is that requiring the permit in this case appears to us to rest on an irrational prejudice against the mentally retarded." $105 \mathrm{~S}$. Ct. at 3260 . The Court reached this conclusion on the particular facts of Cleburne after rejecting all of the justifications proferred by the city. It declined to decide whether a city could never insist on a permit for the mentally retarded. Id. at 3258. 
group is sufficiently subject to prejudice. ${ }^{101}$

Cleburne itself does not resolve these issues, but it does offer some guidance. The community's values were not acceptable bases for the zoning ordinance: "mere negative attitudes, or fear, unsubstantiated by factors which are properly cognizable in a zoning proceeding, are not permissible bases"102 for such a discriminatory classification. Clearly, the Court was looking for, but did not find, some factual proof that the mentally retarded possessed some relevant characteristic that could legitimate this prejudice. ${ }^{103}$ If, for example, there were proof that the mentally retarded as a group were prone to set fires in any neighborhood in which they lived, the community's fears would be objectively supported and related to zoning, and would thus form a rational basis for the ordinance.

Of course, even such a factual determination must be accompanied by some value judgment. For instance, it would be much harder to argue that the community's fears should be respected if the characteristic imputed to the mentally retarded were merely a propensity to sing loudly and off key on the front porch at midnight or a tendency to paint their homes in multi-colored, garish fashion. Ultimately, the Court must make a judgment regarding the importance of the value the community seeks to protect.

2. Political powerlessness. The second race-like aspect of statutory classification that plainly concerned the Court in the 1984 term was the political powerlessness of certain groups. In three cases, the Court invalidated legislation disadvantaging a group whose members could not vote in the state imposing the disadvantage. In Metropolitan Life, the discriminatory action was against the economic activity of out-of-state residents. ${ }^{104}$ Both Williams and Hooper rejected discrimination against newly arrived residents. All three cases taken together portray the Court's significant concern for any residence-based classifications insofar as they may effect discrimination against the politically powerless.

By now it is a common argument that the equal protection clause should primarily protect groups who lack the political power

${ }^{101}$ See Palmore, 466 U.S. at 432 (all race-based classifications must be subject to "the most exacting" scrutiny).

${ }^{102} 105 \mathrm{~S}$. Ct. at 3259 (emphasis added).

103 Professor Perry refers to this as a "contextually relevant difference-i.e., [a] difference relevant in the context of the policy decision being implemented." He goes further to state that equal protection law requires government to refrain from disadvantaging a group for a "morally irrelevant" reason, even if it is contextually relevant. Perry, Modern Equal Protection, 79 Colum. L. Rev. at 1069 (cited in note 13).

104105 S. Ct. at 1678. 
to protect their own interests through the legislative process. ${ }^{105}$ Once again, the experience of blacks serves as the paradigm, for blacks were disenfranchised de jure until 1870 and de facto until only recently. ${ }^{108}$ But once again, the principle extends to other groups as well. Classifications based on length of residency-whether disadvantaging out-of-staters or new arrivals-are relatively obvious examples of actions against the politically powerless. Out-of-state residents and newly arrived citizens were unable to vote, either directly or indirectly through elected representatives, when the particular statute affecting them was passed..$^{107}$

At first glance, then, the residency cases seem easy. Such classifications seem like obvious cases for judicial scrutiny and invalidation of impermissible purposes. But there are several complications. First, the federal government, in which all citizens have participatory rights, may affirmatively authorize discriminatory conduct by the states, as was the case on the facts of Metropolitan Life. ${ }^{103}$ Congressional consent may cure the equal protection defects of legislation that disadvantages those excluded from a particular state's political process; if it does, Metropolitan Life was wrongly decided, in light of federal consent to local regulation of the insurance industry. ${ }^{108}$

105 Chief Justice Stone's opinion in Carolene Products, 304 U.S. at 152 n.4, calls for special protection of "discrete and insular minorities." The most prominent exposition of this process-based equal protection theory is Ely, Democracy and Distrust at 135-79 (cited in note 82), which describes the equal protection clause as the constitutional safeguard against majoritarian self-interest in the political process. Such protection is violated when a group is politically disadvantaged because its members are not able to participate effectively in the political process. The clause thus reinforces the representation process for such "discrete and insular minorities." But see Ackerman, 98 Harv. L. Rev. at 731-37 (cited in note 81 ), arguing that discrete and insular groups are no longer desperately in need of equal protection.

106 The fifteenth amendment, passed in 1870 , had little practical effect on the ability of blacks to vote in the South. For discussion of the "total disfranchisement of the Negro" in the South after Reconstruction, see C. Vann Woodward, The Strange Career of Jim Crow 83-85 (3d ed. 1974). The southern states "set up certain barriers such as property or literacy qualifications [or poll taxes] for voting, and then cut certain loopholes in the barriers through which only white men could squeeze"-e.g., "grandfather" clauses. Id. at 84 . In addition, the white primary operated effectively to disenfranchise blacks in the virtually one-party South. Id. These measures were, for the most part, not effectively dealt with until the Voting Rights Act of 1965. Id. at 186.

107 Consider, e.g., Thomas R. McCoy, Recent Equal Protection Decisions-Fundamental Right to Travel or "Newcomers" as a Suspect Class?, 28 Vand. L. Rev. 987, 1018 (1975): " ' $[N]$ ewcomers' as a class are almost always a minority in the governmental unit, unable to protect their interests through the political process."

108105 S. Ct. at 1685 (O'Connor, J., dissenting).

${ }^{109}$ Id. In a similar case decided soon after Metropolitan Life, the Court unanimously upheld several state statutes favoring businesses in one geographic region over others. 
Apart from the problem of federal authorization peculiar to cases like Metropolitan Life, there are greater difficulties with the notion of "politically powerless." In one sense, any group disfavored by legislation is politically weak; if it were politically powerful, the unfavorable law would not have passed. Moreover, many groups to whom the Court has repeatedly refused to extend greater protection are effectively politically powerless. The mentally retarded are one example; though they can vote in the formal sense, they lack the ability to participate effectively. Still they may be represented adequately through family, teachers, or caretakers. ${ }^{110}$ The most troublesome example is the poor, whose political disadvantages are severe. ${ }^{111} \mathrm{~A}$ serious and principled commitment to protecting the "politically powerless" might entail designating the poor a suspect class and rectifying the inadequacy of their representation through radical wealth redistribution, something the Court has never shown any sign of doing. ${ }^{112}$

Nevertheless, one might defend the Court's focus on the formal right to vote as the best available indicator of political power. To treat the equal protection clause as demanding radical wealth redistribution would ignore those parts of the Constitution that

Northeast Bancorp., $105 \mathrm{~S}$. Ct. at 2545, involved a challenge to several states' banking statutes that, together with the Douglas Amendment to the Bank Holding Company Act of 1956,12 U.S.C. $\$ 1842$ (d) (1982), limited acquisition of in-state banks to bank holding companies located in the New England geographic region. The Court upheld the statutes after applying rationality review. To distinguish Metropolitan Life, Justice Rehnquist's opinion for the Court noted that the disputed statutes favored out-of-state banks rather than instate businesses, and referred to the lengthy and important tradition of local control over banks. $105 \mathrm{~S}$. Ct. at 2555-56. Justice $\mathrm{O}^{\prime}$ Connor's concurrence argued that Ward was indistinguishable from Northeast Bancorp and therefore wrongly decided. Id. at 2556.

When Congress affirmatively authorizes discriminatory legislation, equal protection values that are process-oriented (especially concern for out-of-state residents) are not threatened by statutes that disadvantage those excluded from a particular state's legislative process, although equal protection values that are preference-oriented may be. While congressional action may surely remove commerce clause objections to discriminatory legislation, the implications of congressional consent for equal protection purposes are unclear and controversial. For background, see Jonathan D. Varat, State "Citizenship" and Interstate Equality, 48 U. Chi. L. Rev. 487 (1981).

${ }^{110}$ In Cleburne, in fact, the caretakers, not the mentally retarded themselves, brought suit against the city. $105 \mathrm{~S}$. Ct. at 3252-53.

Another apparent anomaly is that the Court generally has refused to accord special protection to minors, despite their obvious disenfranchisement. The general rationale is that minors are represented by their parents. "Their social integration means that minors, unlike discrete and insular minorities, tend to be treated in legislative arenas with full concern and respect, despite their formal and complete exclusion from the electoral process." Id. at 3272 n.24 (Marshall, J., concurring).

${ }^{111}$ For discussion of this point, see Frank I. Michelman, Foreword: On Protecting the Poor Through the Fourteenth Amendment, 83 Harv. L. Rev. 7 (1969).

112 See Dandridge, 397 U.S. at 471. 
seem to contemplate a system of private property. ${ }^{113}$ The formal right to vote is easily identifiable; by contrast, the inquiry into true "political power" within a state is complex and unruly, and the Court would encounter tremendous difficulties in trying to judge it. For example, when the Court did enter the "political thicket" of legislative apportionment, ${ }^{114}$ it opted for the simple, although arguably arbitrary, principle of "one man, one vote," rather than a complicated investigation of the distribution of power between various political interests in a state. ${ }^{115}$ Not only is the formal franchise a more easily administered line, it finds support in the race paradigm as well: a large factor in the systematic oppression of blacks was their de jure and de facto disenfranchisement. ${ }^{116}$

In short, the fact of residency can be seen as providing a simple, though perhaps imperfect, indicator of political powerlessness that should trigger a more vigorous search for impermissible legislative purposes. The continuing vitality of Zobel $v$. Williams ${ }^{117}$ in the most recent round of residency cases, as well as cites to earlier cases such as Shapiro $v$. Thompson, ${ }^{118}$ show that the Court has consistently recognized this concern in equal protection cases, albeit without explicit reference to political powerlessness. ${ }^{119}$

\section{The Workings of Impermissible Purpose Review}

Whatever the difficulties in application, the two factors considered here-subjective majoritarian distaste and political powerlessness-must play a large part in any coherent equal protection analysis. Where a statute, even one regarding economic or social welfare issues, draws a classification that stems from either of these two bases, the underlying purposes should be held imper-

113 U.S. Const. art. I, § 10, cl. 1 (forbidding states from making laws that impair obligations of contracts), amend. $V$ (forbidding taking of private property for public use without just compensation).

114 Contrast Colegrove v. Green, 328 U.S. 549, 556 (1946) (refusing to enter the "political thicket") with Baker v. Carr, 369 U.S. 186 (1962) (holding challenges to apportionment schemes judicially cognizable under equal protection clause).

115 Reynolds v. Sims, 377 U.S. 533 (1964) (announcing "one man, one vote" standard). Consider Justice Harlan's dissent, id. at 616,622 , criticizing the "one man, one vote" test for failing to take account of factors relevant to representation, such as economic and geographical considerations. For one example of the argument that the "one person, one vote" standard, while perhaps arbitrary, was justified on grounds of judicial manageability, see Ely, Democracy and Distrust at 123-24 (cited in note 82).

116 As to blacks, see note 106 above. Women did not receive the vote until 1920. U.S. Const. amend. XIX.

117457 U.S. 55 (1982).

118 Shapiro, 394 U.S. at 618 (suggesting that interstate travel is a fundamental right).

118457 U.S. at 59-60. 
missible. In such cases, the statute bears a strong resemblance to race-based legislation that is the core concern of the equal protection clause. Such was true of the cases decided in the 1984 term, except perhaps for Metropolitan Life. ${ }^{120}$ Understood in this light, the decisions in these cases do not represent a radical change in the Court's underlying substantive concept of equality.

However, the decisions, if followed in the future, do suggest implications for the method by which the Court enforces the substantive guarantee of equality. They constitute a departure from strict adherence to the Court's traditional three-tiered system of review. Impermissible purpose inquiry differs from traditional rational basis review in the Court's increased willingness to look behind the state's asserted permissible motives to find the true, impermissible ones. If a plaintiff can persuade the Court to engage in such an inquiry in the first place, she is more likely to be successful in getting the Court to overturn the challenged legislation. Because the Court has not clarified in what cases it will undertake to look behind asserted motives for impermissible ones, it appears open for plaintiffs to argue in every rational basis case that the particular statute in question was based on impermissible purposes. The implications of this approach are uncertain. The Court could minimize its effect by refusing in most cases to scrutinize legislation carefully.

Impermissible purpose review also differs substantially from heightened scrutiny. In deciding to apply heightened scrutiny, the Court identifies a class (for example, women, aliens) analogous to race in the disadvantages it suffers (irrational prejudice, political powerlessness); the Court then in all cases subjects classifications of that type to more searching scrutiny. ${ }^{12 x}$ In contrast, impermissible purpose review, as it developed in the 1984 term, does not apply heightened scrutiny per se to an ever-longer list of suspect or quasi-suspect classes. Rather, the approach appears to call for minimal scrutiny unless, on the facts of a particular case, the plaintiff can show that the challenged legislation has arisen from one of the two impermissible bases identified above. ${ }^{122}$

${ }^{120}$ As suggested above in text at notes 108-09, congressional treatment of the issue of discriminatory conduct may provide all the political representation to which a nonresident is entitled.

${ }^{121}$ For example, heightened scrutiny in gender cases developed first case by case, and it was not until Craig $v$. Boren that the Court finally articulated the heightened level of scrutiny applicable to all gender classifications. See note 85 above.

${ }_{122}$ The case of residency lends itself more to drawing a clear line beyond which some form of toughened scrutiny is undertaken; and the Court could develop this into a new 
Such an approach avoids reflexive application of heightened scrutiny when unwarranted, as may not be possible with continued expansion of the "middle tier." Both equal protection values and the value of judicial restraint thus would be served. Because it focuses on individual cases, impermissible purpose review is more slow and tentative in displacing legislative judgments than is an approach that subjects a classification to heightened scrutiny in all cases once the likelihood of prejudice or political powerlessness is shown. Such an approach would be required under the "continuum" and "sliding scale" approaches now favored by Justices Stevens and Marshall, respectively. ${ }^{123}$

In addition, were the Court to make explicit reference to political powerlessness and subjective distaste of classified groups as the salient defects of statutes that fail impermissible purpose review, lower courts and legislators would have a better basis with which to guide their conduct. Finally, stricter review of statutes that are intended to disadvantage the politically powerless (in the limited sense of those formally disenfranchised) should subsume within equal protection doctrine the concerns presented by Justice Brennan's advocacy of a constitutional "right to travel," which has thus far failed to garner majority support on the Court. ${ }^{124}$

\section{Conclusion}

The Court explicitly or implicitly rejected any expansion of the middle tier of equal protection analysis in the 1984 term. Some coherence and legitimacy to the Court's approach to challenged statutes may be found by looking to those categories of legislation that historically have expressed racial animus. The Court must further define the contours of impermissible purpose review-in par-

quasi-suspect class. However, the Northeast Bancorp case, in which the Court upheld a statute under facts quite similar to those in Metropolitan Life, suggests that for the time being the Court will continue to examine residency-based classifications on the facts of each case rather than declare a per se rule of heightened scrutiny. See note 109 above.

${ }^{123}$ Justice Marshall's position is discussed above in note 17 and accompanying text. Justice Stevens's view is described above in note 31 .

${ }^{124}$ In Soto-Lopez, $106 \mathrm{~S}$. Ct. at 2317, 2320-21, Justice Brennan again failed to gain majority support for his conclusion that residency distinctions of the sort at issue implicate a constitutional right to travel.

The analysis proposed here is closest to Chief Justice Burger's view that the equal protection clause is the proper source of protection for nonresidents and new arrivals. See id. at 2326 (concurring opinion). This analysis suggests, however, that the Constitution is offended not by the threat to migration itself-as differing state laws will always change incentives to migrate-but by the legislative intent to disadvantage those who do not have access to the political process or to express a subjective majoritarian prejudice. 
ticular its procedural implications and the extent to which it will be used-but the analogy to race-based classifications provides a preliminary understanding of the substance of impermissible purpose review.

By staying close to the historical basis of the equal protection clause, the race analogy approach avoids the more intrusive judicial role that an expanding middle-tier or a sliding scale approach would engender. Even if the outcomes of particular cases would not change by use of the analogy, at least the legitimacy and authority of the courts' substantive review would be plain. Once impermissible purpose review in the 1984 term is read as limited to statutes that, in a particular case, disadvantage the politically powerless or express invidious majoritarian attitudes, one can understand the Court's decisions as an effort to contain rather than broaden scrutiny of legislation under the equal protection clause while simultaneously ensuring that the core values of the equal protection clause are preserved.

Brenda Swierenga 